\title{
FAKTOR-FAKTOR YANG MEMPENGARUHI KEPATUHAN WAJIB PAJAK ORANG PRIBADI
}

\author{
Nerissa Arviana ${ }^{1}$, Djeni Indrajati $\mathbf{W}^{2}$ \\ ${ }^{1}$ Jurusan S1 Akuntansi, Universitas Pelita Harapan \\ Email : nerissaarviana23@yahoo.com \\ ${ }^{2}$ Jurusan S1 Akuntansi, Universitas Tarumanagara \\ Email : djenii@fe.untar.ac.id
}

\begin{abstract}
ABSTRAK
Beberapa penelitian tentang kepatuhan wajib pajak orang pribadi dengan berbagai variabel bebas telah dilakukan dengan beragam hasil. Penelitian ini bertujuan menguji secara empiris pengaruh pelayanan fiskus, sanksi perpajakan, tingkat pemahaman, kesadaran perpajakan, sosialisasi perpajakan, dan persepsi atas efektifitas perpajakan. Theory of Reasoned Action yang mendasari psikologi sosial adalah teori utama yang dipakai untuk penelitian ini dalam kaitannya denga niat seseorang untuk melakukan atau tidak melakukan suatu, dalam hal ini kepatuhan terhadap perpajakan. Populasi dalam penelitian ini ditentukan dengan menggunakan random sampling, data yang ada didapat dari pembagian kuesioner kepada responden di KPP Kembangan secara acak sederhana.

Metode analisis yang digunakan adalah regresi berganda. Hasil penelitian menunjukkan bahwa pelayanan fiskus memiliki pengaruh positif dan signifikan terhadap kepatuhan wajib pajak. Begitu juga dengan variabel sanksi perpajakan, tingkat pemahaman, kesadaran perpajakan, sosialisasi perpajakan dan persepsi atas efektiftas perpajakan.
\end{abstract}

Kata Kunci : Theory of Reasoned Action (TRA),Pengaruh pelayanan fiskus, sanksi perpajakan, tingkat pemahaman, kesadaran perpajakan, sosialisasi perpajakan, persepsi atas efektifitas perpajakan, kepatuhan wajib pajak.

\section{PENDAHULUAN}

Pajak merupakan pendapatan dalam negeri yang menjadi sumber pembiayaan terbesar negara dalam menjalankan pemerintahan. Dalam hal ini Direktorat Jendral Pajak melakukan banyak cara yang bertujuan untuk meningkatkan pendapatan negara. Beberapa cara yang diupayakan seperti, menambah jumlah wajib pajak aktif, memperluas objek yang dikenakan pajak, meningkatkan tarif pajak tertentu, meningkatkan pelayanan dan pengawasan serta pemeriksaan terhadap wajib pajak, dan lain-lain. Hal tersebut bertujuan untuk meningkatkan pendapatan Negara dari sektor pajak yang dimulai dengan langkah-langkah meningkatkan kepatuhan wajib pajak dalam memenuhi kewajiban perpajakannya.

Untuk memenuhi kewajiban perpajakan, wajib pajak harus memiliki sikap patuh. Kepatuhan dalam perpajakan merupakan suatu hal yang sangat penting untuk mengoptimalisasi penerimaan pajak. Hal ini dikarenakan pemerintah Indonesia pada saat ini menggunakan self assessment system, dimana setiap wajib pajak diberi keleluasaan untuk membayar, menyetor, dan melaporkan besarnya pajak terutang sesuai dalam jangka waktu yang telah ditentukan dalam peraturan perundang-undangan perpajakan (Mardiasmo, 2006). Dengan kata lain, wajib pajak dituntut untuk selalu aktif dalam memenuhi kewajiban perpajakannya mulai dari mendaftarkan diri, mengisi SPT dengan jujur, baik, dan benar sampai dengan melunasi pajak terutang.

Penelitian Arum (2012) menyebutkan bahwa untuk meningkatkan kepatuhan wajib pajak dalam pemenuhan kewajiban perpajakan, kualitas pelayanan pajak harus ditingkatkan oleh petugas pajak. Keramahan petugas pajak dan kemudahan dalam sistem informasi perpajakan termasuk dalam pelayanan perpajakan tersebut. Penelitian Jatmiko (2006) juga menyebutkan bahwa pelayanan fiskus terhadap wajib pajak memiliki pengaruh positif yang bersifat signifikan

Keberhasilan dalam perpajakan dipengaruhi oleh pengetahuan wajib pajak terhadap undang-undang, peraturan perpajakan dan sikap wajib pajak dalam mematuhi kewajiban perpajakan (Sholicah, 2005). Pengetahuan yang luas sangat penting untuk meningkatkan penerimaan pajak dan akan berpengaruh dalam pembayaran pajak, semakin tinggi tingkat pengetahuan dan pemahaman wajib pajak terhadap peraturan perpajakan, maka semakin banyak wajib pajak yang akan memenuhi peraturan tersebut.

Penyebab lainnya adalah kesadaran wajib pajak. Hal ini telah dibuktikan, dimana berpengaruh terhadap penerimaan perpajakan. Kesadaran wajib pajak yang rendah seringkali banyak menimbulkan potensi pajak yang tidak baik. Apabila wajib pajak memiliki tingkat kesadaran yang rendah, maka akan berpotensi tinggi untuk tidak menjalankan kewajiban perpajakannya atau melanggar peraturan perpajakan yang berlaku. 


\section{TINJAUAN PUSTAKA}

\section{Theory of Reasoned Action (TRA)}

Teori yang mendasari psikologi sosial ini dikembangkan oleh Fishbein dan Ajzen. Ia menyatakan bahwa niat, menentukan seseorang untuk melakukan atau tidak melakukan sesuatu perilaku. Dalam teori tersebut juga dikemukakan niat seseorang didasari oleh dua penentu utama yaitu: Sikap dan Norma subjektif.

Kaitannya dengan penelitian ini adalah bahwa seseorang dalam menentukan sikap patuh atau tidak patuh dalam memenuhi kewajiban perpajakannya dipengaruhi rasionalitas dalam mempertimbangkan manfaat dari pajak dan juga pengaruh orang lain yang mempengaruhi keputusan dalam patuh pajak. Hal tersebut bersifat signifikan dengan pelayanan fiskus, sosialisasi perpajakan, dan persepsi atas efektivitas sistem perpajakan. Dengan pelayanan yang baik dari petugas fiskus, kemudahan yang didapat dalam melaksanakan kewajiban perpajakan melalui sistem yang modern, dan pemahaman yang didapat dari sosialisasi tentang perpajakan akan menimbulkan persepsi yang baik dari para wajib pajak. Hal tersebut akan mempengaruhi dan mendorong para wajib pajak untuk bersikap patuh pada pajak.

\section{Pengertian Pajak}

Undang-Undang Nomor 16 Tahun 2009 tentang Ketentuan Umum dan Tata Cara Perpajakan pada pasal 1 ayat 1 menyatakan Pajak adalah kontribusi wajib kepada negara yang terutang oleh orang pribadi atau badan yang bersifat memaksa berdasarkan undang-undang, dengan tidak mendapatkan imbalan secara langsung dan digunakan untuk keperluan negara bagi sebesar-besarnya kemakmuran rakyat. Sedangkan Wajib pajak adalah orang pribadi atau badan yang memiliki hak dan kewajiban yang terdiri dari pembayar pajak, pemungut pajak, pemotong pajak yang diatur dalam perundang-undangan perpajakan

\section{Kepatuhan Perpajakan}

Kepatuhan pajak dapat disamakan dengan kesediaan seorang wajib pajak dalam memenuhi peraturan perpajakannya. Menurut Nurmanto, Devano, dan Rahayu (2006), kepatuhan perpajakan adalah suatu keadaan dimana wajib pajak memenuhi semua kewajiban perpajakannya.Kepatuhan formal dalam perpajakan dapat dilakukan dengan cara menghitung, membayar, dan menyampaikan SPT. Dalam hal ini wajib pajak dituntut untuk bersikap jujur dalam menyetor, melaporkan, dan menyampaikan SPT sesuai dengan pendapatan yang diterima. Penyampaian SPT harus sesuai undang-undangan $\mathrm{PPh}$ dan harus disampaikan pada Kantor Pelayanan Pajak sebelum batas waktunya.

\section{Pelayanan Fiskus}

Pelayanan dari fiskus ikut menjadi bagian dalam memenuhi kepatuhan wajib pajak dalam membayarkan pajaknya. Oleh sebab itu, fiskus dituntut untuk bersikap ramah, adil, tegas setiap saat kepada setiap wajib pajak. Hal ini bertujuan agar para wajib pajak memiliki kesadaran untuk memenuhi kewajiban perpajakannya. Untuk menilai suatu kualitas pelayanan terdapat lima indikator antara lain Kehandalan (Reliability), Ketanggapan (Responsive), Jaminan (assurance), Empati (Emphaty) dan Wujud fisik (Tangibility). Dapat disimpulkan bahwa pelayanan fiskus memiliki pengaruh yang sangat besar terhadap kepatuhan wajib pajak dalam memenuhi kewajibannya.

\section{Sanksi Perpajakan}

Sanksi adalah suatu langkah berupa hukuman yang diberikan kepada orang yang melanggar peraturan. Dalam Undang-Undang Perpajakan terdapat dua macam sanksi, yaitu sanksi administrasi dan sanksi pidana. Sanksi administrasi akan diberikan kepada wajib pajak yang melanggar norma perpajakan. Sanksi administrasi berkaitan dengan kerugian negara seperti denda, bunga, dan kenaikan. Sedangkan sanksi pidana akan diberikan kepada wajib pajak berupa kurungan atau penjara.

\section{Tingkat pemahaman}

Menurut Suryadi (2006) tingkat pemahaman mengenai peraturan perpajakan merupakan proses dimana wajib pajak (WP) mengetahui mengenai perpajakan dan mengaplikasikan pengetahuan tersebut untuk pembayaran pajak.Untuk meningkatkan kepatuhan wajib pajak maka wajib pajak harus memahami dan mengerti tentang hak dan kewajibannya sebagai wajib pajak.

\section{Kesadaran perpajakan}


Menurut Kamus Umum Bahasa Indonesia kesadaran adalah suatu keadaan tahu, mengerti, dan merasa. Kesadaran wajib pajak adalah suatu kondisi dimana wajib pajak mengetahui, memahami, dan melaksanakan ketentuan perpajakan dengan benar dan sukarela. Wajib pajak harus melaksanakan aturan itu dengan benar dan sukarela..

\section{Sosialisasi perpajakan}

Menurut Sugeng Wahono (2012) sosialisasi perpajakan adalah suatu upaya yang diberikan oleh Dirjen Pajak dalam memberitahukan sebuah pemahaman baik dalam bentuk peraturan ataupun dalam bentuk tata cara perpajakan dengan menggunakan metode-metode yang tepat kepada masyarakat khususnya wajib pajak. Sosialisasi perpajakan dapat dilakukan dengan berbagai cara atau bentuk yang tepat dan efektif. Salah satunya bisa dengan menggunakan media-media sosial agar dapat diketahui oleh banyak orang.

\section{Persepsi atas efektifitas perpajakan}

Menurtu Sutari (2013) persepsi atas efektifitas dalam sistem perpajakan merupakan proses bagaimana wajib pajak dalam menilai, memahami, menafsirkan suatu keadaan atau peristiwa mengenai efektifitas sistem perpajakan apakah proses tersebut mempermudah atau malah mempersulit wajib pajak. Untuk mengetahui efektifitas sistem perpajakan dapat dinilai melalui beberapa fasilitas antara lain dengan e-filling, e-SPT, e-NPWP, e-banking, dsb.

\section{Penelitian terdahulu}

Irmawati (2015) menguji pengaruh kesadaran wajib pajak, sanksi perpajakan, dan pemahaman perpajakan terhadap kepatuhan wajib pajak. Variabel bebas yang digunakan adalah kesadaran wajib pajak, sanksi perpajakan, dan pemahaman perpajakan, sedangkan variabel terikat yang digunakan adalah kepatuhan wajib pajak. Penelitian ini memakai teknik regresi linear berganda. Hasil yang dicapai dari penelitian ini adalah kesadaran perpajakan memiliki pengaruh positif terhadap kepatuhan perpajakan. Sedangkan dalam sanksi perpajakan dikatakan bahwa memiliki pengaruh negatif terhadap kepatuhan wajib pajak. Hasil ini mendukung beberapa penelitian, misalnya oleh Siti Masruroh (2013) Dan untuk pemahaman perpajakan juga memiliki pengaruh positif terhadap kepatuhan wajib pajak. Jika disimpulkan maka pemahaman perpajakan memilki sikap paling dominan terhadap kepatuhan wajib pajak.

Penelitian Widowati (2015) menguji sanksi perpajakan, pengetahuan pajak, dan kualitas pelayanan fiskus serta sosialisasi perpajakan. Hasil yang diperoleh dari penelitian ini adalah sosialisasi perpajakan, sanksi perpajakan, dan pengetahuan perpajakan, memiliki pengaruh secara signifikan terhadap kepatuhan perpajakan. Sedangkan pelayanan fiskus tidak berpengaruh secara signifikan terhadap kepatuhan wajib pajak. Penelitian ini bertolak belakang dengan penelitian Kartika dan Sihar (2016), dimana sosialisasi perpajakan tidak berpengaruh terhadap kepatuhan wajib pajak.

\section{METODE PENELITIAN}

\section{Populasi dan Sampel}

Populasi yang diambil untuk penelitian ini adalah wajib pajak orang pribadi yang telah terdaftar di KPP Pratama Kembangan, Jakarta Barat dengan jumlah 73.718 wajib pajak orang pribadi. Oleh sebab itu, dilakukan pengambilan sampel. Menurut Muliari dan Setiawan (2010) penentuan sampel dapat ditentukan dengan memakai rumus yaitu:

$$
\begin{aligned}
& \quad n=\frac{N}{1+N(e)^{2}} \\
& \mathrm{~N}=\text { populasi } \\
& \mathrm{n}=\text { Jumlah sampel } \\
& \mathrm{e}=\text { persen kelonggaran ketidaktelitian karena kesalahan pengambilan sampel yang masih dapat ditolerir, } \\
& \text { dalam penelitian ini adalah } 10 \% \text {. } \\
& \text { Berdasarkan data yang diperoleh dari KPP Pratama Kembangan, wajib pajak pusat yang aktif adalah } \\
& \text { sebanyak 73718. Dan probabilitas yang digunakan untuk penelitian adalah sebesar 10\%: }
\end{aligned}
$$




$$
n=\frac{73718}{1+73718(0,1)^{2}}
$$

$$
=99,8
$$

Setelah melakukan perhitungan, maka jumlah yang diperoleh untuk dijadikan sampel adalah sebanyak 100 wajib pajak orang pribadi. Jenis yang digunakan untuk pengambilan sampel adalah random sampling/acak sederhana.

\section{Variabel Penelitian}

Terdiri dari 1 variabel Dependen yaitu Kepatuhan Perpajakan dan 6 variable Independen yaitu Pelayanan Fiskus, Sanksi Perpajakan, Tingkat Pemahaman, Kesadaran Perpajakan, Sosialisasi Perpajakan dan Persepsi atas efektifitas Perpajakan.

\section{Metode Pengumpulan Data}

Metode pengumpulan data primer yang dipakai adalah metode survei melalui media angket atau kuesioner. Dalam mengukur pendapat para responden, penelitian ini menggunakan skala Likert, dimana skala ini dipakai untuk mengukur pendapat atau sikap.

Skala Likert menyediakan tingkat persetujuan yang terdiri dari lima angka yang mana dimulai dari angka tertinggi angka lima untuk pendapat sangat setuju (SS) dan yang paling rendah angka satu untuk pendapat sangat tidak setuju (STS). Berikut perinciannya:

Angka 1 = Sangat Tidak Setuju (STS)

Angka 2 = Tidak Setuju (TS)

Angka $3=\operatorname{Netral}(\mathrm{N})$

Angka $4=$ Setuju (S)

Angka 5 = Sangat Setuju (SS)

\section{Hipotesis Penelitian}

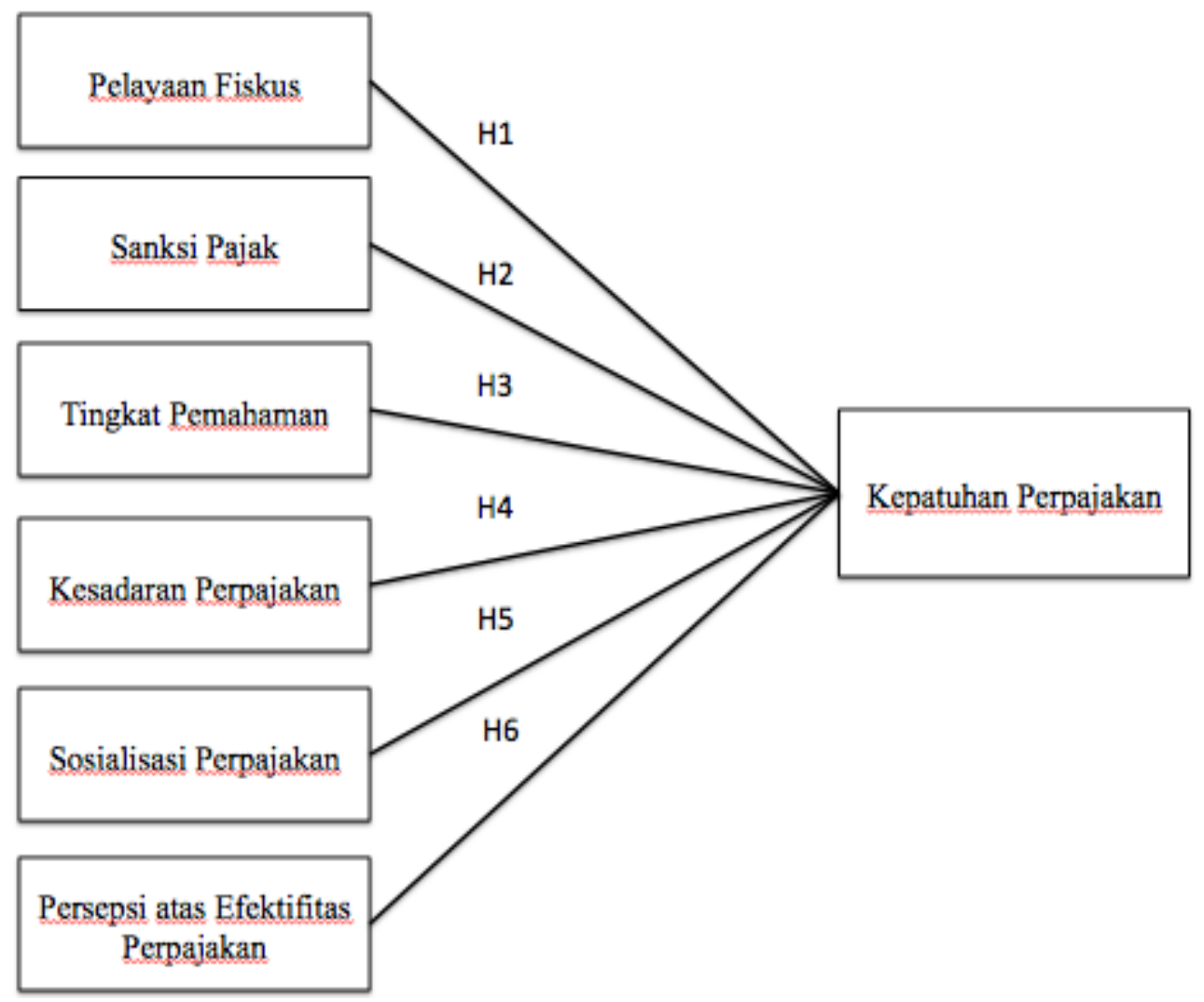

Gambar 3.1.Bagan Model Penelitian 
Hipotesis merupakan jawaban sementara terhadap permasalahan dalam suatu penelitian. Hipotesis yang diuji dalam penelitian adalah :

H1: Pelayanan fiskus memiliki pengaruh terhadap kepatuhan wajib pajak

H2: Sanksi pajak memiliki pengaruh terhadap kepatuhan wajib pajak

H3: Tingkat pemahaman memiliki pengaruh terhadap kepatuhan wajibPaj pajak

H4: Kesadaran perpajakan memiliki pengaruh terhdap kepatuhan wajib pajak

H5: Sosialisasi perpajakan memiliki pengaruh terhadap kepatuhan wajib pajak

H6:Persepsi atas efektifitas perpajakan memiliki pengaruh terhadap kepatuhan wajib pajak

Metode Analisis

Uji Statistik Deskriptif

Untuk menguji kuesioner yang telah dibagikan kepada responden, akan dilakukan pengujian pertama dengan 25 responden dan untuk memastikan validitasnya maka akan dilakukan pengujian kembali dengan 75 responden. Pengujian ini dikatakan valid apabila $r_{\text {hitung }}>r_{\text {tabel }}$.

bel 3.1 Hasil Analisis Reliabilitas

Case Processing Summary

\begin{tabular}{|ll|r|r|}
\hline & & \multicolumn{1}{|c|}{$\mathrm{N}$} & \multicolumn{1}{c|}{$\%$} \\
\hline \multirow{3}{*}{ Cases } & Valid $^{*}$ & 25 & 100.0 \\
& Excluded $^{\mathrm{a}}$ & 0 & .0 \\
& Total & 25 & 100.0 \\
\hline
\end{tabular}

a. Listwise deletion based on all variables in

the procedure.

Reliability Statistics

\begin{tabular}{|r|r|}
\hline $\begin{array}{c}\text { Cronbach's } \\
\text { Alpha }\end{array}$ & N of Items \\
\hline .760 & 5 \\
\hline
\end{tabular}

\section{Model Regresi}

Penelitian ini menggunakan teknik analisis regresi dengan menggunakan program SPPS. Rumus yang digunakan untuk mencari regresi linear berganda adalah sebagai berikut:

$K e P=\alpha+\beta_{1} P F+\beta_{2} S a P+\beta_{3} T P+\beta_{4} K s P+\beta_{5} S o P+\beta_{6} P E P+\mathrm{e}$

Dimana:

$\mathrm{KeP}=$ Kepatuhan perpajakan

$P F=$ Pelayanan Fiskus

$S a P=$ Sanksi Perpajakan

$T P=$ Tingkat Pemahaman

$K s P=$ Kesadaran Perpajakan

$S o P=$ Sosialisasi Perpajakan

$P E P=$ Persepsi atas Efektifitas Perpajakan

$a=$ Konstanta

$\beta_{1}, \beta_{2}, \beta_{3}, \beta_{4}, \beta_{5}, \beta_{6}=$ Koefisien regresi

$\mathrm{e}=$ Error 


\section{ANALISIS DAN PEMBAHASAN \\ Tempat dan Objek Penelitian}

Objek penelitian yang digunakan adalah para wajib pajak yang telah terdaftar di Kantor Pelayanan Pajak (KPP) Pratama Kembangan yang beralamat di Duri Kepa Jakarta Barat. Kuesioner yang dibagikan terdiri dari 100 buah, dan diuji sebanyak 100 responden. Jadi, kusioner yang dapat diolah dari kusioner yang dibagikan adalah 100 kusioner atau 100\%.

\section{Data Responden}

Setelah mengumpulkan kuesioner, maka dapat dilihat profil dari wajib pajak KPP Pratama Kembangan berdasarkan kepemilikan NPWP, jenis kelamin, usia, dan jenis pekerjaan pada Tabel.2.

\section{Tabel 2 Profil Wajib Pajak}

\begin{tabular}{|c|c|c|c|}
\hline Keterangan & Diskripsi & Jumlah & Presentase \\
\hline \multirow{2}{*}{ Kepemilikan NPWP } & Ya & 82 & $82 \%$ \\
& Tidak & 18 & $18 \%$ \\
\hline \multirow{2}{*}{ Jenis Kelamin } & Pria & 78 & $78 \%$ \\
& Wanita & 22 & $22 \%$ \\
\hline \multirow{3}{*}{ Usia } & $25-35$ tahun & 76 & $76 \%$ \\
& $36-45$ tahun & 20 & $20 \%$ \\
& $46-55$ tahun & 4 & $4 \%$ \\
& $>56$ tahun & - & - \\
\hline \multirow{3}{*}{ Jenis Pekerjaan } & Karyawan & 75 & $75 \%$ \\
& Wirausaha & 21 & $21 \%$ \\
& Tidak Bekerja & 4 & $4 \%$ \\
\hline
\end{tabular}

Sumber : Data Diolah Oleh Peneliti (Januari, 2018)

\section{Uji Statistik Deskriptif}

Dapat dilihat dalam tabel-tabel berikut:

Tabel 3 Hasil Uji Statistik Deskriptif Variabel $\mathbf{X}_{1}$

\begin{tabular}{|l|r|r|r|r|r|}
\hline & \multicolumn{1}{|c|}{$\mathrm{N}$} & \multicolumn{1}{|c|}{ Minimum } & Maximum & Mean & Std. Deviation \\
\hline PF1 & 75 & 1 & 5 & 4.12 & .636 \\
\hline PF2 & 75 & 2 & 5 & 3.73 & .644 \\
\hline PF3 & 75 & 1 & 5 & 4.09 & .619 \\
\hline PF4 & 75 & 2 & 5 & 4.04 & .478 \\
\hline PF5 & 75 & 3 & 5 & 4.21 & .576 \\
\hline $\begin{array}{l}\text { Valid N } \\
\text { (listwise) }\end{array}$ & 75 & & & & \\
\hline
\end{tabular}

Sumber: Output SPSS Febuari, 2018

Dalam Tabel 3 dapat dilihat bahwa lima pertanyaan dalam variabel Pelayanan Fiskus memiliki nilai minimum dari 1 sampai dengan 3 dan nilai maksimum 5 dengan nilai rata-rata pada masing-masing pertanyaan sebagai berikut PF1 dengan nilai rata-rata 4,12; PF 2 dengan nilai rata-rata 3,73; PF3 dengan nilai 


\section{WAJIB PAJAK ORANG PRIBADI}

rata-rata 4,09; PF4 dengan nilai rata-rata 4,04; dan PF5 dengan nilai rata-rata 4,21. Secara keseluruhan variabel telah lolos uji asumsi klasik.

\section{Koefisien Korelasi $\left(\mathbf{R}^{2}\right)$}

Tabel 4 Koefisien Determinasi

\begin{tabular}{|l|r|r|r|r|}
\hline Model & $\mathrm{R}$ & $\mathrm{R}$ Square & $\begin{array}{c}\text { Adjusted R } \\
\text { Square }\end{array}$ & $\begin{array}{c}\text { Std. Error of the } \\
\text { Estimate }\end{array}$ \\
\hline 1 & $.797^{\mathrm{a}}$ & .635 & .603 & 1.336 \\
\hline \multicolumn{4}{|l}{ a. Predictors: (Constant), PEP, SaP, PF, KsP, SoP, TP } \\
\hline
\end{tabular}

\section{Sumber: Output SPSS Febuari, 2018}

Menurut hasil dari Tabel 4, nilai dari R sebesar 0.797 yang mana berarti hubungan antara variabel independen memiliki pengaruh cukup signifikan terhadap variabel dependennya. Selanjutnya adalah nilai dari koefisien determinasi (Adjusted R Square) adalah 0.60, dimana 60\% dari variabel independen yaitu pelayanan fiskus $(\mathrm{PF})$, sanksi perpajakan $(\mathrm{SaP})$, tingkat pemahaman $(\mathrm{TP})$, kesadaran perpajakan (KsP), sosialisasi perpajakan (SP), dan persepsi atas efektifitas perpajakan memiliki kontribusi terhadap variabel dependen dan sisanya $40 \%$ dapat dijelaskan melalui variabel lain.

\section{Uji F (Signifikan Simultan)}

Simultan regresi (Uji F) dilakukan untuk mengetahui apakah semua variabel independen yang dibuat memiliki pengaruh secara bersama-sama terhadap variabel depnden. Hasil uji F terdapat dalam Tabel 5.

Tabel 5 Hasil Uji F

\begin{tabular}{|l|l|r|r|r|r|c|}
\hline \multicolumn{2}{|c|}{ Model } & \multicolumn{1}{c|}{$\begin{array}{c}\text { Sum of } \\
\text { Squares }\end{array}$} & \multicolumn{1}{c|}{ df } & $\begin{array}{c}\text { Mean } \\
\text { Square }\end{array}$ & F & Sig. \\
\hline \multirow{3}{*}{1} & $\begin{array}{l}\text { Regressio } \\
\mathrm{n}\end{array}$ & 211.574 & 6 & 35.262 & 19.749 & $.000^{\mathrm{b}}$ \\
\cline { 2 - 7 } & Residual & 121.413 & 68 & 1.785 & & \\
\cline { 2 - 7 } & Total & 332.987 & 74 & & & \\
\hline \multicolumn{2}{|l}{ a. Dependent Variable: KeP } \\
\hline
\end{tabular}

Sumber: Output SPSS Febuari, 2018

Berdasarkan hasil dalam tabel diatas, nilai $F$ adalah 19.749 dengan signifikansi 0.000 . Nilai signifikansi kurang dari 0.05 (5\%). Oleh karena itu, dapat disimpulkan bahwa model yang dipakai untuk menguji variabel merupakan model yang tepat.

\section{Uji Signifikan Partial (t-test)}

Dalam pengujian $\mathrm{t}$ (t-test) bertujuan untuk menguji seberapa jauh pengaruh antara variabel independen terhadap variabel dependen. Jika hasil signifikansi lebih kecil dari 0.05 , maka terdapat pengaruh yang signifikan. Hasil uji t terdapat dalam Tabel 6 
Tabel 6 Hasil Uji t (t-test)

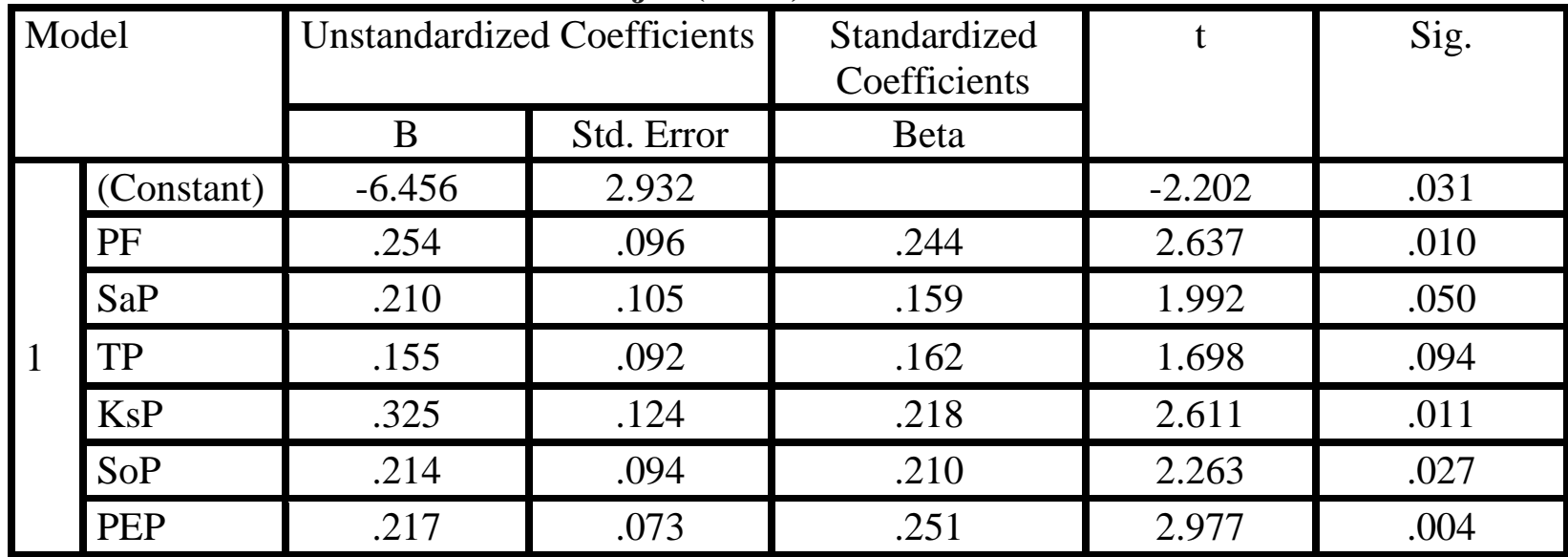

a. Dependent Variable: KeP

Sumber: Output SPSS Febuari, 2018

Berdasarkan hasil pengujian menggunakan SPSS 24 diperoleh hasil seperti di Tabel 6.

Dari tabel tersebut dapat diperoleh model regresi sebagai berikut:

$\mathrm{KeP}=-6.456+0.254 \mathrm{PF}+0.210 \mathrm{SaP}+0.155 \mathrm{TP}+0.325 \mathrm{KsP}+0.214 \mathrm{SoP}+0.217 \mathrm{PEP}+\mathrm{e}$

\section{KESIMPULAN DAN SARAN}

\section{Kesimpulan}

Berdasarkan pembahasan pada bab sebelumnya, maka dapat ditarik kesimpulansebagai berikut:

1.Terdapat pengaruh positif dan signifikan terhadap pelayanan fiskus. Hal ini menunjukkan bahwa semakin baik pelayanan fiskus yang diberikan, maka semakin tinggi tingkat kepatuhan wajib pajak dalam memenuhi kewajiban perpajakannya.

2.Terdapat pengaruh positif dan signifikan terhadap sanksi perpajakan. Hal ini menunjukkan bahwa semakin banyak wajib pajak yang enggan melanggar peraturan perpajakan.

3.Terdapat pengaruh positif dan signifikan terhadap tingkat pemahaman. Hal ini menunjukkan bahwa semakin tinggi tingkat pemahaman mengenai perpajakan, maka semakin banyak wajib pajak yang akan patuh terhadap peraturan perpajakan.

4.Terdapat pengaruh positif dan dan signifikan terhadap kesadaran perpajakan. Hal ini menunjukkan semakin tinggi tingkat kesadaran para wajib pajak terhadap kewajiban perpajakannya, maka meningakatkan kepatuhan perpajakannya.

5.Terdapat pengaruh positif dan signifikan terhadap sosialisasi perpajakan. Hal ini menunjukkan semakin sering diberikan sosialisasi perpajakan, maka semakin tinggi tingkat keinginan wajib pajak dalam memenuhi kewajiban perpajakannya.

6.Terdapat pengaruh positif dan signifikan terhadap persepsi atas efektifitas perpajakan. Hal ini ditunjukkan dengan semakin besar tingkat kemudahan yang diberikan oleh kantor pajak, maka semakin banyak juga wajib pajak yang akan akan memenuhi kewajiban perpajakannya.

\section{Saran}

Berdasarkan kesimpulan yang telah dikemukakan bahwa pelayanan fiskus, sanksi perpajakan, tingkat pemahaman, kesadaran perpajakan, sosialisasi perpajakan, dan persepsi atas efektifitas perpajakan telah terbukti memberikan pengaruh positif dan signifikan terhadap kepatuhan perpajakan, maka disarankan agar fiskus terus memberi penyuluhan dan kemudahan bagi para wajib pajak dalam memenuhi kewajiban perpajakannya. Untuk penelitian selanjutnya dapat digunakan teknik wawancara dan menambah jumlah responden serta memperluas ruang lingkup penelitian. 


\section{WAJIB PAJAK ORANG PRIBADI}

\section{ACKNOWLEDGEMENT :}

Terima Kasih kepada Bapak Rektor UPH dan UNTAR, Bapak Dekan FE UPH dan UNTAR, Bapak Direktur DPPM UNTAR, rekan peneliti dan pengolah data serta berbagai pihak yang telah membantu dan meberi semangat.

\section{REFERENSI :}

Devano, Sony dan Siti Kurnia Rahayu. 2006. Perpajakan Konsep, Teori dan Isu. Jakarta : Kencana Prenada Media Group.

Ghozali, Imam. (2016). Aplikasi Analisis Multivariete dengan Program IBM SPSS 21. Semarang: Badan Penerbit Universitas Diponegoro.

Handayani, Kartika Ratna., Tambun, Sihar. 2015. Pengaruh Penerapan Sistem E-filling dan Pengetahuan Perpajakan Terhadap Kepatuhan Wajib Pajak Dengan Sosialisasi Sebagai Variabel Moderating. E-journal, Vol.1, No.2. Jakarta.

Irmawati, Agnes Sophia. 2015. Pengaruh Kesadaran Wajib Pajak, Sanksi Perpajakan, dan Pemahaman Perpajakan Terhadap Kepatuhan Wajib Pajak. Skripsi: FE Universitas Darma Persada.Jakarta.

Jatmiko, A.N. 2006. "Pengaruh Sikap Wajib Pajak pada Pelaksanaan Sanksi Denda, Pelayanan Fiskus dan Kesadaran Perpajakan terhadap Kepatuhan Wajib Pajak(Studi Empiris terhadap Wajib Pajak Orang Pribadi di Kota Semarang)'”.Tesis Magister Akuntansi Program Pascasarjana Universitas Diponegoro. Undang-Undang Pajak Penghasilan No.16/2009. Ketentuan Umum dan Perpajakan.

Mardiasmo. 2016. Perpajakan Edisi Revisi, Penerbit Andi, Yogyakarta.

Masruroh, Siti. 2013. Pengaruh Kemanfaatan NPWP, Pemahaman Wajib Pajak, Kualitas Pelayanan, Sanksi Perpajakan Terhadap Kepatuhan Wajib Pajak. E-Journal-S.Undip.ac.Vol. 2, No.4. Semarang.

Puspa, Arum. 2012. Pengaruh Kesadaran Wajib Pajak, Pelayanan Fiskus, dan Sanksi Pajak Terhadap Kepatuhan Wajib Pajak Orang Pribadi yang Melakukan Kegiatan Usaha dan Pekerjaan Bebas. Skripsi : FE UNDIP Semarang.

Widowati, Rizky. 2015. Kepatuhan Wajib Pajak Melalui Sosialisasi Perpajakan, Sanksi Perpajakan, Pengetahuan Pajak dan Pelayanan Fiskus. Tugas Akhir. Universitas Dian Nuswantor. Semarang.

Sholicah, Mu'minatus dan Istiqomah. 2005. Perilaku Wajib Pajak terhadap Tingkat Keberhasilan Penerimaan PBB di Kabupaten Gresik. Jurnal Logos. Vol 3 No. 1 Juli 2005

Sugeng Wahono. 2012. Teori dan Aplikasi: Mengurus Pajak itu Mudah. Mojokerto: Gramedia Direct. Suryadi. 2006. Model kausal kesadaran, pelayanan, kepatuhan wajib pajak, dan pengaruhnya terhadap kinerja penerimaan pajak. Jurnal Keuangan Publik.Volume 4.No.1:105- 121.

Sutari dan Dewi Kusuma Wardani, "Faktor-Faktor yang mempengaruh 